\title{
Perspektif Minat Orang Tua Siswa dalam Memilih Sekolah Dasar (SD) Berbasis Zonasi di Kec. Majenang Kab. Cilacap Jawa Tengah
}

\section{Azamul Fadhly Noor Muhammad}

STKIP Majenang

fadhlee46@gmail.com

\section{Article History}

received $8 / 12 / 2020$

revised $21 / 01 / 2021$

accepted 2/4/2021

\begin{abstract}
This study aims to determine the perceptions of parents in choosing primary schools for their children. The subjects of this study are parents who have children aged $6-7$ years or the age of the child entering grade 1 of elementary school in several villages in Majenang District, Cilacap Regency, Central Java. The research method used in this research is descriptive qualitative. The results of this study indicate that (1) the process of admitting new students (PPDB) based on zoning in the Majenang District, Cilacap Regency. perceptions of parental interest in choosing zoning-based elementary schools (SD): (a) the process of implementing new PPDB student admissions is carried out procedurally and structurally based on the existing system. (2) Parents 'perceptions of interest in choosing Zoning-based SDs: (a) Parents' understanding of choosing zoning-based elementary schools. (b) the impact of zoning policy according to parents of students in choosing elementary schools (SD). (c) Parents' perceptions of interest in choosing Zoning-based Elementary Schools (SD). (d) parents' perceptions of interest regarding the solution in choosing a Zoning-based Elementary School (SD). The solution desired by parents of students: this policy should be reviewed by the government, the provision of distance is expanded, there is socialization and the percentage of student admissions is more balanced.. Keywords: Perception, Parents Interest, Zoning, Elementary School (SD).
\end{abstract}

\begin{abstract}
Abstrak
Penelitian ini bertujuan untuk mengetahui persepsi orang tua dalam memilih SD untuk anaknya. Subyek penelitian ini adalah orang tua yang mempunyai anak berusia sekitar $6-7$ tahun atau usia anak masuk kelas 1 sekolah dasar di beberapa desa di Kec. Majenang Kab. Cilacap Jawa Tengah. Metode penelitian yang digunakan dalam penelitian ini adalah kualitatif deskriptif. Hasil penelitian ini menunjukan bahwa (1) proses penerimaan peserta didik baru (PPDB) berbasis Zonasi di wilayah Kec. Majenang Kab. Cilacap. persepsi minat orang tua dalam memilih Sekolah Dasar (SD) berbasis zonasi: (a) proses pelaksanaan PPDB dilakukan secara prosedural dan terstruktur berdasarkan sistem yang ada. (2) persepsi minat orang tua siswa dalam memilih SD berbasis Zonasi: (a) Pemahaman orang tua siswa dalam memilih SD berbasis zonasi. (b) dampak kebijakan zonasi menurut orang tua siswa dalam memilih SD. (c) persepsi minat orang tua siswa dalam memilih SD berbasis Zonasi. (d) persepsi minat orang tua siswa mengenai solusi dalam memilih SD berbasis Zonasi. Solusi yang diinginkan oleh orang tua siswa : kebijakan ini harap dikaji ulang oleh pemerintah, ketentuan jarak diperluas, diadakan sosialisasi dan presentase kuota penerimaan peserta didik lebih seimbang.
\end{abstract}

Kata kunci: Persepsi, Minat Orang Tua, Zonasi, Sekolah Dasar (SD). 


\section{PENDAHULUAN}

Sekolah merupakan lembaga pendidikan formal yang memegang peranan yang sangat penting dalam mencapai tujuan pendidikan nasional. Pencapaian tujuan tersebut bisa digapai melalui interaksi pembelajaran dalam lingkungan yang saling mendukung, terstruktur dan terarah. Sekolah sebagai pusat pendidikan formal lahir dan berkembang dari pemikiran efisiensi dan efektivitas pemberian pendidikan kepada masyarakat (Sutapa, 2009).

Sekolah Dasar (SD) merupakan sekolah formal yang pertama bagi anak. Kenyataan ini sangat penting sebagai penanaman nilai dan norma serta sebagai penentu keberhasilan Pendidikan selanjutnya. Sekolah dasar termasuk dalam lingkup pendidikan dasar yang kini wajib diikuti warga Indonesia. Sekolah dasar menjadi pondasi awal bagi anak sebagai modal melanjutkan ke jenjang yang lebih tinggi. Komponen sistem pendidikan sekolah dasar secara garis besar terdiri dari siswa sebagai bahan masukan (raw input), komponen instrumental, lingkungan, dan tujuan yang harus dicapai (output) (Suharjo, 2006).

Pendidikan dasar diharapkan menjadi tonggak dari keberhasilan jenjang pendidikan selanjutnya (Verdiyani, 2016). Pendidikan di sekolah dasar menjadi pendidikan formal pertama yang mempunyai posisi yang strategis dalam menyelenggarakan pendidikan untuk siswa. Pendidikan di sekolah dasar menjadi langkah pertama bagi anak untuk masuk jenjang pendidikan selanjutnya. Jenjang ini merupakan jenjang pendidikan yang penting sebagai langkah persiapan anak untuk mendapatkan kemampuan dasar ataupun untuk melanjutkan ke jenjang yang lebih tinggi. Keberhasilan pada jenjang pendidikan di sekolah dasar dapat menentukan keberhasilan pada jenjang pendidikan selanjutnya. Persepsi seperti inilah yang membuat orang tua akan berusaha memaksimalkan kemampuan anak dan menempatkannya di sekolah yang memang mempunyai reputasi dan kredibilitas yang tinggi di masing-masing daerah. Usaha dari orang tua ini yang sekarang sedang hangat diperbincangkan oleh semua orang.

Penerimaan Siswa Baru / Penerimaan Peserta Didik Baru (PPDB) mulai Tahun Pelajaran 2017/2018 diberlakukan Sistem Zonasi secara menyeluruh di Indonesia sebagai mana di atur dalam Permendikbud No. 17 Tahun 2017, baik ditingkat SD, SMP, maupun SMA yang milik pemerintah (Negeri). Akan tetapi di Kecamatan Majenang Kab. Cilacap mulai diberlakukan mulai tahun pelajaran 2019/2020. Pemerintah melalui Permendikbud No. 44 Tahun 2019 (Kemendikbud, 2019) menjelaskan bahwa penerapan sistem ini tidak lain adalah untuk pemerataan siswa pada setiap sekolah baik ditingkat SD, SMP, maupun SMA. Akan tetapi dalam pengaplikasiannya di lapangan, terutama di Kec. Majenang Kab. Cilacap tidak bisa berjalan sesuai dengan harapan dari pemerintah. Sehingga muncullah berbagai polemik yang terjadi. Antara lain dari perspektif kedinasan, perspektif sekolah, perspektif orangtua siswa, dan yang lain sebagainya.

Berdasarkan penjabaran diatas, maka peneliti tertarik untuk melakukan suatu penelitian dalam hal mengungkap fakta-fakta di lapangan mengenai sistem zonasi dari segi perspektif minat orang tua dalam memilih Sekolah Dasar (SD) yang akan menjadi sekolah buah hatinya kelak.

Konsep Sekolah Zonasi dalam proses penerimaan peserta didik baru (PPDB) merupakan suatu kegiatan yang rutin dilakukan setiap sekolah di semua jenjang pada tahun pelajaran baru. PPDB yang dilakukan di setiap sekolah tentunya harus mempunya aturan yang telah ditetapkan oleh pemerintah. Mulai tahun pelajaran 2019/2020 pemerintah mengumumkan pemberlakuan sistem zonasi keseluruh sekolah di Indonesia. Pada tahun pelajaran 2020/2021 diperkirakan juga akan melaksanakan sistem zonasi ini. Berikut adalah beberapa peraturan dari pasal-pasal Permendikbud No. 17 tahun 2017 yang telah direvisi menjadi Permendikbud No. 44 tahun 2019 (Kemendikbud, 2019) tentang penerimaan peserta didik baru (PPDB). Permendikbud 
ini mengatur tentang syarat, proses seleksi, sistem zonasi, proses pendaftaran ulang, dan Rombongan Belajar seperti kutipan berikut, 1) Persyaratan PPDB untuk tingkat SD; 2) Proses Seleksi PPDB untuk tingkat SD; 3) Sistem Zonasi untuk Tingkat SD; 4) Proses Pendaftaran Ulang untuk Tingkat SD; dan 5) Rombongan Belajar untuk Tingkat SD.

Pada ranah persepsi orangtua dalam memilih sekolah dasar bagi anaknya, perlu diperhatikan perkembangan ilmu pengetahuan dan teknologi yang semakin maju yang harus diikuti oleh masyarakat salah satunya melalui sistem pendidikan yang maju (Zainal, 2013). Seperti sistem yang terbaru saat ini yang berlaku di Indonesia adalah pemberlakuakn sistem zonasi dalam PPDB. Sistem ini menimbulkan pro dan kontra dikalangan orangtua siswa yang akan menyekolahkan putra-putrinya, baik ditingkat ditingkat SD, SMP maupun SMA milik pemerintah. Pada tingkat pendidikan dasar yang dimulai dari tingkat SD, diharapkan menjadi tonggak dari keberhasilan jenjang pendidikan selanjutnya (Verdiyani, 2016). Pendidikan di sekolah dasar menjadi pendidikan formal pertama yang mempunyai posisi yang strategis dalam menyelenggarakan pendidikan untuk siswa. Pendidikan di sekolah dasar menjadi langkah pertama bagi anak untuk masuk jenjang pendidikan selanjutnya. Jenjang ini merupakan jenjang pendidikan yang penting sebagai langkah persiapan anak untuk mendapatkan kemampuan dasar ataupun untuk melanjutkan ke jenjang yang lebih tinggi. Persepsi seperti inilah yang membuat orang tua akan berusaha memaksimalkan kemampuan anak dan menempatkannya di sekolah yang memang mempunyai reputasi dan kredibilitas yang tinggi di masing-masing daerah.

Sebagaimana hasil penelitian yang dilakukan oleh (Andini, 2010) variabel yang paling berpengaruh adalah persepsi lokasi sekolah. Penelitian yang dilakukan oleh ( $\mathrm{Li}$ \& Hung, 2009) menyimpulkan bahwa variabel promosi merupakan faktor yang paling mempengaruhi diikuti oleh variabel kualitas SDM, produk dan biaya. Sedangkan peneliti (Suprayogi, 2008) menyimpulkan bahwa variabel yang paling berpengaruh adalah motivasi. Peneliti (Bidmon et al., 2008), memaparkan hasil dari penelitiannya yaitu bahwa loyalitas mempunyai pengaruh yang lebih dominan terhadap suatu merk. Berbeda dengan hasil penelitian (Li \& Hung, 2009) bahwa variabel yang paling signifikan atau berpengaruh adalah promosi sedangkan variabel lokasi merupakan variabel yang tidak berpengaruh. Peneliti (Rauyruen et al., 2009) memaparkan bahwa persepsi kualitas pelayanan dan kepercayaan terhadap penyedia jasa mempunyai peran penting terhadap loyalitas konsumen pelanggan.

Dari kajian hasil penelitan diatas, maka dapat disimpulkan bahwa persepsi orang tua atau pelanggan dalam memilih sekolah atau produk yang akan dibeli adalah harus memenuhi berbagai aspek, diantaranya lokasi sekolah, promosi, kualitas SDM, produk, biaya, motivasi, loyalitas, kualitas pelayanan dan kepercayaan penyedia jasa. Pelanggan yang loyal akan bersedia untuk membayar produk walaupun dengan harga yang mahal.

\section{METODE}

Penelitian ini menggunakan metode penelitian Kualitatif deskriptif. Teknik yang digunakan dalam menentukan subyek penelitian ini adalah purposive. Purposive sampling adalah suatu teknik yang digunakan untuk menentukan sumber data dengan suatu pertimbangan tertentu (Sugiyono, 2011). Pertimbangan yang dimaksud adalah pihak-pihak yang paling mengetahui tentang apa yang ingin kita ketahui, atau pihak yang memudahkan peneliti menjelajahi atau mengeksplor objek/situasi sosial yang ingin diteliti. Subyek penelitian ini adalah orang tua yang mempunyai anak berusia sekitar $6-7$ tahun atau usia anak masuk kelas 1 sekolah dasar di beberapa desa di Kec. Majenang Kab. Cilacap Jawa Tengah.

Teknik pengumpulan data yang digunakan pada penelitian ini adalah observasi, wawancara, dan dokumentasi. Penelitian ini menggunakan obervasi partisipatif pasif, 
yaitu peneliti datang ke tempat kegiatan yang akan diamati, akan tetapi tidak ikut terlibat dalam suatu kegiatan. Peneliti menggunakan wawancara semi terstruktur dalam penelitian yang akan dilakukan. Peneliti dapat bebas bertanya mengatur alur dan setting wawancara, serta mengandalkan pedoman wawancara kepada subyek penelitian sebagai pedoman penggalian data. Wawancara semi terstruktur dapat menggunakan pertanyaan lainnya diluar pedoman wawancara karena perkembangan data dari informan. Pengumpulan data dengan dokumentasi berupa catatan/bukti pada saat wawancara, gambar sekolah terdekat dengan informan dan lainnya sebagaimana data dokumentasi yang dibutuhkan.

Penelitian ini, direncanakan menggunakan teknik analisis data kualitatif (Miles \& Huberman, 1992). Aktivitas dalam analisis data yaitu data reduction, data display, dan conclusion drawing / verification: 1) Data Reduction (Reduksi Data), Mereduksi data yang dimaksud adalah merangkum, memilih dan memilah hal-hal pokok, memfokuskan pada hal yang penting, dicari tema dan pola yang muncul. 2) Data Display (Penyajian Data), Penyajian data yang dimaksud adalah peneliti melakukan penyajian data dalam bentuk uraian singkat, bagan, hubungan antar kategori, flowcharti dan sejenisnya. 3) Conclusion Drawing / Verificatio, Peneliti melakukan penarikan kesimpulan berdasarkan hasil penelitian dan pembahasan. Keabsahan data dalam penelitian ii adalah uji credibility dan uji dependability. Uji credibility yang digunakan adalah teknik trianggulangi dan member check. Uji dependibility dalam penelitian ini dilakukan oleh teman sejawat atau unsur pimpinan P3M STKIP Majenang yang melakukan bimbingan selama penelitian.

\section{HASIL DAN PEMBAHASAN \\ A. Penerimaan Peserta Didik Baru Tingkat Sekolah Dasar (SD) Tahun 2020 di Kecamatan Majenang Kab. Cilacap Jawa Tengah}

Berdasarkan paparan dan temuan data di lapangan, proses Penerimaan Peserta Didik Baru (PPDB) dalam kebijakan Sistem Zonasi di Kec. Majenang Kab. Cilacap Jawa Tengah dapat dikategorikan sebagai PPDB yang sistematik Informatif, dimana proses secara prosedural dan informatif. Hasil dari penelitian ini, proses PPDB dilakukan dengan tahapan sebagai berikut:

Pertama, pengorganisasian dimana dalam proses penerimaan peserta didik baru (PPDB) di tingkat sekolah dasar (SD) di seluruh kec. Majenang kab. Cilacap membentuk panitia PPDB yang terdiri dari Kepala Sekolah, guru, dan warga sekolah lainnya. Dalam temuan di lapangan, salah satu sekolah yang dikunjungi oleh peneliti adalah SDN Jenang $05 \mathrm{Kec}$. Majenang Kab. Cilacap telah membentuk kepanitian PPDB yang diketuai oleh Waka Kesiswaan yaitu Ibu Sri Wahyuningsih, S.Pd.SD. Proses PPDB dapat berjalan dengan lancar dan baik sesuai dnegan harapan. Hal in dibuktikan dengan kelengkapan berkas PPDB secara teknis yang sesuai dengan yang telah ditetapkan oleh pemerintah dan didistribusikan oleh Dinas Pendidikan Kab. Cilacap.

Kedua, Rapat penentuan Penerimaan Peserta Didik Baru (PPDB). Dimulai dengan perencanaan awal PPDB, perencanaan tersebut diawali dengan kegiatan penyusunan kepanitiaan masing-masing Sekolah Dasar (SD) di lingkungan Kec. Majenang Kab. Cilacap, masing-masing Sekolah Dasar (SD) menyiapkan format formulir, menyiapkan spanduk atau brosur serta melakukan rapat untuk memberikan tugas atau tanggungjawab kepada panitia PPDB masing-masing Sekolah Dasar (SD) di lingkungan Kec. Majenang.

Ketiga, pembuatan pengumuman Peserta didik baru. Pada tahap ini, salah satu SD yang dikunjungi oleh peneliti adalah SDN Jenang $05 \mathrm{Kec}$. Majenang Kab. Cilacap memberikan pengumuman bagi calon peserta didik baru melalui banner yang dipasang di pintu masuk sekolah dasar dan melalui sosial media Whatsapp orang tua siswa. Hal tersebut bertujuan untuk memberikan informasi sedetail 
mungkin kepada calon peserta didik yang ingin mendaftar agar tidak ada kebingungan atau kesalahan informasi yang didapat.

Keempat, pendaftaran peserta didik baru. Pendaftaran calon peserta didik sekolah dasar di lingkungan Kec. Majenang rata-rata dilakukan dengan 2 gelombang. Untuk gelombang pertama dilakukan melalui jalur zonasi. Dan gelombang kedua melalui jalur prestasi dan jalur perpindahan orang tua. Pihak sekolah menyediakan tempat pendaftaran di sekolah. Selain itu juga pihak sekolah menyediakan nomor telepon panitia PPDB kepada masyarakat agar mempermudah dan tidak harus keluar rumah agar tidak terjadi hal-hal yang tidak diinginkan terkait Covid-19.

Persyaratan calon peserta didik baru meliputi: 1) Akta Kelahiran / Surat Keterangan Lahir; 2) Kartu Keluarga (KK) / Surat Keterangan Domisili; 3) Formulir Pendaftaran; 4) ljazah atau Surat Keterangan Lulus dari Taman Kanak-Kanak (Bila Ada).

Kelima, Tahap seleksi peserta didik baru. Pada tahap ini terdapat 3 sistem seleksi yang digunakan oleh semua sekolah dasar (SD) di lingkungan kec. Majenang dalam proses penerimaan peserta didik baru. Hal itu juga sejalan dengan juknis PPDB yang diterbitkan oleh pemerintah melalui Dinas Pendidikan Kab. Cilacap Jawa Tengah, yaitu sistem jalur zonasi sebanyak $90 \%$, jalur perpindahan orangtua sebanyak $5 \%$, dan jalur prestasi $5 \%$. Kuota jalur prestasi ini juga dibagi menjadi jalur prestasi akademik dan non akademik. Analisis didasarkan pada kebutuhan sekolah untuk siswa dengan kualifikasi untuk pencapaian di bidang tertentu yang belum tersedia. Maka, diharapkan masukan ini akan melengkapi dan memenuhi kebutuhan sekolah untuk bimbingan lebih lanjut.

Keenam, Pengumuman peserta didik yang diterima. Setelah pihak sekolah menyelesaikan kegiatan penyeleksian siswa berdasarkan tiga (3) unsur, maka panitia PPDB di masing-masing SD Sekecamatan Majenang menentukan siswa mana yang diterima, yang menjadi cadangan dan tidak diterima. Maka, selanjutnya pihak panitia PPDB membuat dan memasang daftar nama-nama siswa tersebut di papan pengumuman. Selain melalui papan pengumuman, pihak panitia juga memberikan informasi tersebut melalui media sosial seperti Whatsapp, Instagram, dll.

Ketujuh, Proses Daftar Ulang peserta didik baru. Setelah pengumuman, peserta didik yang dinayatakan diterima maka proses selanjutnya adalah proses daftar ulang. Calon peserta didik baru yang dinyatakan diterima wajib untuk daftar ulang dengan membawa persyaratan lengkap sesuai dengan ketentuan pihak sekolah masing-masing. Calon peserta didik yang tidak melakukan proses daftar ulang, maka dinyakatakan gugur atau tidak bisa menjadi salah satu siswa disekolah tersebut dan digantikan oleh siswa yang masuk kategori cadangan.

B. Perspektif Minat Orang Tua Siswa dalam Memilih Sekolah Dasar (SD) Berbasis Zonasi di Kec. Majenang Kab. Cilacap Jawa Tengah

1. Pemahaman Orang tua siswa dalam memilih Sekolah Dasar (SD) Berbasis Zonasi

Pemahaman orang tua siswa mengenai kebijakan zonasi yang berlaku di lingkungan kec. Majenang Kab. Cilacap adalah kebijakan atau aturan yang dibuat oleh pemerintah dalam proses PPDB berdasarkan jarak antara rumah ke sekolah. Hal ini bertujuan untuk pemerataan kualitas pendidikan sehingga tidak ada lagi gelar sekolah favorit atau sekolah unggulan. Penjelasan tersebut sejalan dengan Permendikbud n0. 17 tahun 2017 pasal 2 yang berbunyi bahwa proses PPDB bertujuan untuk menjamin proses PPDB berjalan dengan objektif, akuntabel, transparan dan tanpa deskriminasi sehingga mendorong mutu layanan pendidikan. 
Dari hasil temuan di lapangan, banyak sekali orang tua siswa yang paham tentang kebijakan ini, akan tetapi hanya sekedar paham pengertian dasar tentang zonasi (jarak) saja. Banyak orang tua siswa yang masih menganggap awam tentang kebijakan ini. Kurangnya sosialisasi dari pemerintah mengenai sistem zonasi banyak orang tua siswa yang belum memahami secara detail tentang kebijakan zonasi ini. Menurut beberapa orang tua siswa, kebijakan ini adalah proses PPDB yang didasarkan pada jarak saja. Dan hal itu juga diambil dari jarak rumah ke sekolah. Dan yang sebenarnya adalah terdapat tiga (3) jalur, yaitu jalur zona (jarak), jalur prestasi, dan jalur perpindahan orang tua. Kenyataan di lapangan, banyak orang tua siswa yang mengetahui tentang aturan jarak tersebut, akan tetapi orang tua siswa tetap mendaftarkan anak-anaknya ke sekolah yang berjarak lebih dari $3 \mathrm{~km}$ atau melebihi ketentuan yang berlaku pada kebijakan ini.

Hal tersebut yang menyebabkan persepsi tidak setuju beberapa orang tua siswa terhadap kebijakan ini, karena tidak ada sosialisasi atau pengumuman tentang kebijakan ini. Selain itu juga terdapat beberapa masalah yang lainya, diantaranya adalah ketidakadaanya sekolah dengan jarak maksimal $3 \mathrm{~km}$ dari rumah orang tua tersebut, orang tua siswa ingin memberikan pendidikan yang maksimal pada anak-anaknya sehingga menyekolahkannya ke sekolah tengah kota dengan harapan mendapatkan pelayanan pendidikan yang memadai. Sementara itu, tujuan dari kebijakan ini sebenarnya baik dan relevan untuk pemerataan fasilitas penunjang pendidikan yang ada di Indonesia. Namun, karena ketidakpahaman orang tua siswa secara mendalam atau detail, malah menimbulkan banyak sekali tanggapan yang tidak setuju atau menolak kebijakan ini.

2. Dampak Kebijakan Zonasi Menurut Orang Tua Siswa dalam memilih Sekolah Dasar (SD)

Suatu kebijakan pasti akan menimbulkan dampak, baik itu dampak positif maupun dampak negatif. Begitu pula kebijakan zonasi ini yang menimbulkan dampak bagi orang tua siswa sekolah dasar (SD) di lingkungan Kec. Majenang Kab. Cilacap. Kebijakan zonasi ini dibagi menjadi 3 jalur, yaitu jalur zona (jarak), jalur prestasi, dan jalur perpindahan orang tua. Jalur zona (jarak) yang dimaksud adalah zona (jarak) antara rumah orang tua ke sekolah. Jalur prestasi yang dimaksud adalah jalur yang mana dikhususkan untuk siswa yang mempunyai prestasi baik ditingkat kecamatan, kabupaten, provinsi, maupun nasional baik itu akademik maupun non akademik. Sementara jalur perpindahan yang dimaksud adalah jalur peserta didik yang orang tuanya mutasi pekerjaan / tempat tinggal kedaerah tersebut. Dengan ketiga jalur tersebut, diharapkan orang tua siswa lebih mudah mengontrol dan memantau anaknya baik di rumah maupun di lingkungan sekolah.

Kebijakan zonasi ini secara tidak langsung melatih siswa untuk bersaing secara sehat, mandiri dan menambah prestasi baik akademik dan non akademik agar bisa masuk ke sekolah yang diinginkan. Selain itu, diharapkan siswa lebih termotivasi dan bersemangat untuk mengembangkan potensi, bakat dan minat setiap siswa. Jalur ini akan memudahkan siswa untuk masuk ke sekolah yang diinginkan walaupun daya tampung untuk jalur ini hanya $5 \%$ dari $100 \%$ kuota yang dibutuhkan. Jalur ini hanya tinggal melampirkan piagam kejuaraan lomba saja.

Berdasarkan temuan data di lapangan, peneliti menemukan beberapa dampak positif dan dampak negatif, diantaranya: 


\section{a. Dampak Positif}

Dampak positif dari penerapan kebijakan zonasi yang dilakukan pemerintah untuk proses PPDB di lingkungan kec. Majenang Kab. Cilacap sebagai berikut: 1) Peraturan yang dibuat oleh pemerintah berdasarkan jarak antara rumah dengan sekolah. Dengan jarak paling jauh $3 \mathrm{~km}$. Ini berlaku untuk kategori jalur Zona (jarak). Hal ini sesuai dengan peraturan yang dibuat oleh pemerintah dalam permendikbud no. 17 tahun 2017 yang telah direvisi menjadi no. 44 tahun 2019; 2) Orang tua siswa dapat mengawasi pergaulan anak dengan mudah, baik di sekolah maupun lingkungan rumah. Dengan kebijakan ini, orang tua dengan sangat mudah melakukan pengawasan terhadap anak-anaknya. Mulai dari pergaulan, pertemanan, dan apapun yang berhubungan dengan anaknya; 3) Kebijakan zonasi ini secara tidak langsung dapat melatih siswa agar memiliki ras apercaya diri yang tinggi. Karena, persaingan antara siswa satu dengan yang lainnya begitu ketat agar dapat masuk kesekolah yang diinginkan; 4) Dalam kebijakan ini juga terdapat jalur prestasi yang ditentukan oleh pemerintah. Jalur ini memudahkan siswa untuk masuk ke sekolah yang diinginkan dengan hanya melampirkan piagam prestasi akademik maupun non akademik yang dimiliki oleh siswa tersebut pada saat proses pendaftarannya. Walaupun jalur ini hanya mempunyai kuota $5 \%$ dari $100 \%$, akan tetapi sangat membantu para siswa yang mempunyai prestasi dalam bidang akademik maupun non akademik. Hal ini sesuai dengan Permendikbud no 17 tahun 2017 yang telah direvisi No 44 tahun 2019.

\section{b. Dampak Negatif}

Sistem kebijakan zonasi dalam PPDB ini banyak sekali menimbulkan dampak negatif menurut persepsi beberapa orang tua. Karena dengan adanya kebijakan ini beberapa orang tua tidak bisa memilih sekolah sesuai dengan keinginannya, bahkan ada beberapa pernyataan yang menyebutkan bahwa kebijakan ini berusaha untuk memutus tali dari hak asasi manusia. Sehingga mereka dipaksa untuk mematuhi aturan yang telah dibuat oleh pemerintah. Dari hasil wawancara dengan beberapa orang tua siswa menyatakan bahwa tekanan kepada guru yang berdampak pada siswa. Yang mana, menimbulkan persepsi di masyarakat bahwa sekolah harus mengutamakan akses murid terhadap sekolah berdasarkan domisili bukan dari hasil nilai yang mana telah menjadi mekanisme konvensional dalam penerimaan siswa baru. Selain itu, pihak sekolah juga menganggap hal tersebut dapat menurunkan rangking prestasi sekolah yang selama ini sudah diperjuangkan oleh masing-masing sekolah yang notabene sekolah tersebut berlabel sekolah favorit.

Dampak negatif lainnya yang dirasakan oleh beberapa orang tua murid adalah cukup tidak adil dalam beberapa hal dari kebijakan ini. Sekolah memiliki citra dan prestasi masing-masing yang dibangun selama beberapa dekade, namun terancam hilang dalam waktu dekat. Penerapan kebijakan PPDB berbasis zonasi ini membuat keadaan semakin rumit. Hal ini dikarenakan adanya beraneka ragam sifat / kemampuan siswa, berkumpulnya siswa yang memiliki kemampuan dan sifat yang berbeda-beda karakter membuat sekolah harus berusaha lebih ekstra dalam hal mendidik akademik maupun non akademik. Peran guru disini sangatlah vital dan dituntut lebih aktif untuk mengatasi siswa dengan kemampuan yang tidak merata tersebut sehingga membuat agar prestasinya dapat meningkat baik dalam hal akademik maupun non akademik. Dampak paling signifikan adalah kebijakan ini dianggap dapat memutus tali hak asasi siswa maupun orang tua dalam memilih sekolah sesuai dengan kemauannya. Dengan adanya kebijakan ini, siswa tidak bisa bersekolah sesuai dengan keinginannya karena keterbatasan pagu yang telah ditetapkan oleh pemerintah. Siswa mempunyai asumsi bahwa setinggi atau sepintar apapun 
pada saat di taman kanak-kanak mereka tidak bisa memilih sekolah di tingkat selanjutnya.

3. Persepsi Minat Orang Tua Siswa Dalam Memilih Sekolah Dasar (SD) Berbasis Zonasi Di Kec. Majenang Kab. Cilacap.

Permasalahan ini berhubungan dengan persepsi orang tua siswa dalam memilih sekolah dasar (SD) berbasis Zonasi di lingkungan Kec. Majenang Kab. Cilacap yang berisi tentang apakah orang tua siswa setuju atau tidak. Kalau setuju masalahnya karena apa. Sebenarnya masalah ini hanya pada siswa tidak bisa memilih sekolah yang diinginkan. Akan tetapi dari data di lapangan, dari 50 orang tua siswa yang diwawancara, terdapat 37 orang tua siswa yang tidak setuju dengan kebijakan ini. Orang tua yang tidak menyetujui merasa cemas dan kecewa terhadap pemerintah. Karena tidak dapat menyekolahkan anak di sekolah favorit.

Kebijakan zonasi ini dianggap tidak adil bahkan memutus tali hak asasi manusia karena yang digunakan sebagai patokan untuk masuk sekolah ialah jarak. Nilai dan kepintaran siswa sudah tidak dianggap lagi sebagai prasyarat masuk sekolah. Anak menjadi putus asa dan berdampak psikososialnya menurun bagi siswa. Setiap anak berhak mendaparkan pendidikan, memilih pendidikan sesuai dengan yang mereka inginkan. Kebijakan ini perlu dikaji ulang, karena tidak adanya sosialisasi pada orang tua dan tidak mempertimbangkan keadaan sekolah di wilayah pedalaman yang masih jarang sekali sekolah. Selain itu, anak yang mempunyai kecerdasan dan kepintaran diatas rata-rata dapat disingkirkan oleh siswa dengan kemampuan standar yang memiliki rumah dekat dengan sekolah. Hal ini merupakan tindakan ketidakadilan menurut orang tua siswa atau bisa disebut deskriminasi dalam bidang pendidikan. Hal tersebut bertentangan dengan permendikbud no 17 tahun 2018 yang menjelaskan tentang tanpa deskriminasi di dalam pendidikan.

Dari hasil penelitian di lapangan orang tua siswa menjadi resah dan kecewa terhadap kebijakan zonasi yang ditetapkan oleh pemerintah ini. Banyak sekali orang tua yang menganggap kebijakan ini tidak sejalan dengan semestinya, malah membuat orang tua siswa bingung menyekolahkan anaknya yang mana didaerahnya dalam jarak $3 \mathrm{~km}$ tidak ada sekolah dasar (SD). Hal tersebut sesuai dnegan teori persepsi dalam bidang aspek-aspek persepsi, yaitu aspek afektif yang berhubungan erat dengan rasa senang dan tidak senang. Jadi, sifat evaluatif yang berhubungan erat dengan nilai-nilai kebudayaan atau sistem nilai yang dimiliki. Berdasarkan realitanya, tanggapan orang tua siswa menjadi nilai yang efektif untuk mengevaluasi suatu kebijakan yang ditetapkan. Karena orang tua siswa merupakan komponen utama masyarakat yang menjadi obyek penerapan pada kebijakan zonasi ini. Selain itu dalam aspek ini juga menggambarkan rasa tidak senang orang tua siswa mengenai kebijakan ini.

4. Persepsi Minat Orang Tua Siswa Mengenai Solusi Dalam Memilih Sekolah Dasar (SD) Berbasis Zonasi Di Kec. Majenang Kab. Cilacap

Kebijakan zonasi ini dianggap tidak adil bahkan dianggap memutus tali hak asasi manusia dalam hal ini siswa. Kebijakan ini juga mengundang beberapa orang yang pro dan kontra di kehidupan orang tua siswa. Seperti halnya masalah pada umumnya, untuk mengatasi sebuah masalah maka diperlukan solusi yang terbaik untuk seluruh masyarakat di lingkungan Kec. Majenang Kab. Cilacap. Solusi tersebut merupakan sebuah cara yang dilakukan untuk mengatasi seseorang yang terlilit sebuah masalah. Kebijakan zonasi pun demikian, dibutuhkan sebuah solusi untuk mengatasi kontra yang ada pada orang tua siswa.

Dalam temuan di lapangan, solusi yang digunakan ialah sosialisasi. Sosialisas tentang kebijakan zonasi ini oleh pemerintah dalam proses PPDB 
Sekolah Dasar (SD) di lingkungan Kec. Majenang Kab. Cilacap dianggap sangat penting, hal ini akan mempermudah orang tua siswa maupun masyarakat pada umumnya agar memahami tentang kebijakan ini. Akan tetapi pada kenyataan di lapangan, masih sangat kurangnya sosialisasi yang dilakukan oleh masyarakat setempat untuk orang tua siswa atau masyarakat pada umumnya, sehingga banyak orang tua siswa yang tidak begitu memahami tentang kebijakan zonasi ini. Pada kanyataannya, kebijakan ini telah berjalan kurang lebih 4 tahun yang lalu, akan tetapi bagi orang tua siswa yang anaknya mau masuk sekolah dasar (SD) sangat awam pada kebijakan ini. Sosialisasi itu sangat penting dilakukan agar orang tua siswa atau masyarakat pada umumnya memahami kebijakan zonasi ini yang telah ditetapkan oleh pemerintah.

Pada saat pelaksanaan wawancara di lapangan, banyak orang tua siswa yang kurang memahami kebijakan zonasi ini. Orang tua siswa kebingungan atau tidak memahami mengenai kebijakan ini. Sebenarnya tujuan dari kebijakan ini sangatlah baik, yaitu untuk proses pemerataan fasilitas pendidikan terutama untuk daerah 3T. Akan tetapi kenyataan di lapangan, pemerintah kurang memahami pemetaan daerah yang tepat menggunakan kebijakan ini. Alhasil, banyak orang tua siswa atau masyarakat umum yang pro dan kontra atas kebijakan ini. Seharusnya pemerintah memberikan fasilitas yang merata terlebih dahulu, mulai dari mutu guru sampai dengan saran dan prasarana terutama bagi sekolah di daerah 3T.

Berikut beberapa solusi yang ditawarkan oleh orang tua siswa atas kebijakan sistem zonasi ini: a) Orang tua mengharapkan sebaiknya pemerintah tidak membatasi dalam hal jarak dalam pemilihan sekolah bagi siswa. Karena hanya membuat anak menjadi patah semangat dalam hal belajar; b) Sosialisasi sangatlah penting dalam pendistribusian atau penyampaian tentang kebijakan sistem zonasi yang telah ditetapkan oleh pemerintah; c) Tujuan dari kebijakan ini adalah tentang pemerataan kualitas pendidikan di Indonesia. Akan tetapi, pemerintah melupakan beberapa aspik yang dijadikan dasar dalam kehidupan pendidikan. Pemerintah harus adil dalam pembagian fasilitas pendukung pendidikan di daerah 3T; d) Penambahan jumlah kuota PPDB. Pada jalur zona (jarak) lebih dikurangi atau seimbang menjadi $50 \%: 50 \%$; e) Ketentuan jarak yang ditetapkan seharusnya lebih luas atau dikecualikan untuk daerah 3T. Sehingga penyaringan siswa lebih efektif lagi agar siswa yang memiliki jarak tempuh lebih jauh dari sekolah masih mempunyai harapan untuk sekolah dan siswa yang memiliki jalur prestasi dapat memilih sekolah sesuai dengan keinginan.

\section{SIMPULAN}

Berdasarkan hasil penelitian yang telah dipaparkan di atas, maka peneliti menyimpulkan bahwa tujuan penelitian ini untuk mengetahui persepsi minat orang tua siswa dalam memilih sekolah dasar (SD) berbasis Zonasi Di kec. Majenang Kab. Cilacap Jawa Tengah Tahun ajaran 2020/2021 sebagai berikut:

1. Proses penerimaan peserta didik baru (PPDB) dalam implementasi kebijakan sistem zonasi di Kec. Majenang dilaksanakan secara Sistematik. Proses pelaksanaan PPDB yang sistematik adalah proses pelaksanaan yang dilakukan secara prosedural dan terstruktur berdasarkan sistem yang ada. Diantaranya dengan melakukan analisis kebutuhan sekolah terhadap peserta didik, membentuk kepanitiaan, melaksanakan proses PPDB berbasis zonasi dengan merujuk pada petunjuk teknis PPDB Dinas Pendidikan Kabupaten Cilacap selaku pengawas.

2. Persepsi minat orang tua siswa dalam memilih sekolah dasar (SD) berbasis Zonasi. a. Pemahaman orang tua siswa mengenai kebijakan zonasi 
Kebijakan zonasi merupakan proses penerimaan peserta didik baru yang didasarkan pada jarak, yaitu jarak antara rumah ke sekolah.

b. Dampak penerapan kebijakan sistem zonasi sekolah dasar (SD) di Kec. Majenang Kab. Cilacap.

1) Dampak Positif

a) orang tua siswa tidak repot memikirkan uang untuk biaya transportasi

b) orang tua siswa mudah mengawasi pergaulan anak di sekolah maupun di lingkungan rumah.

c) sistem zonasi secara tidak langsung dapat melatih sifat mandiri anak untuk persaingan agar bisa masuk ke sekolah yang diinginkan.

d) kebijakan sistem zonasi sekolah dengan adanya jalur prestasi akan memudahkan anak untuk diterima di sekolah tersebut hanya dengan melampirkan piagam atau sertifikat kejuaraan yang dimilikinya.

2) Dampak Negatif

a) anak tidak bisa memilih sekolah sesuai dengan keinginannya.

b) pemerataan fasilitas yang belum sesuai dengan apa yang diinginkan pemerintah

c. Persepsi Minat Orang Tua Siswa Dalam Memilih Sekolah Dasar (SD) Berbasis Zonasi Di Kec. Majenang Kab. Cilacap

Kebijakan zonasi ini dirasa kurang adil atau memutus tali hak asasi siswa karena hanya fokus pada jarak antara rumah ke sekolah saja, sedangkan unsur kepintaran dan atau nilai di Pendidikan sebelumnya tidak menjadi pertimbangan untuk masuk sekolah dasar (SD). Kebijakan ini perlu dikaji ulang karena tidak adanya sosialisasi yang beredar, padahal sebelumnya PPDB ini atau kebijakan zonasi ini telah diberlakukan selama 4 tahun yang lalu.

d. Persepsi Minat Orang Tua Siswa Mengenai Solusi Dalam Memilih Sekolah Dasar (SD) Berbasis Zonasi Di Kec. Majenang Kab. Cilacap.

1) Kebijakan perlu dikaji ulang oleh pemerintah

2) Ketentuan jarak sebaiknya perlu diperluas

3) Orang tua siswa mengharapkan pemerintah untuk mengadakan sosialisasi terlebih dahulu agar tidak timbul pro dan kontra di kalangan orang tua siswa dan masyarakat pada umumnya.

4) Prosesntase yang digunakan sebaiknya lebih seimbang, yaitu jarak $50 \%$, prestasi $50 \%$.

\section{DAFTAR PUSTAKA}

Andini, N. (2010). Analisis Pengaruh Persepsi terhadap Keputusan Orang Tua Murid Memilih Jasa Pendidikan di SDIT Bina Insani Semarang. Diponegoro Univercity of Semarang.

Bidmon, S., Grabner- Kräuter, S., \& Matzler, K. (2008). Risk aversion and brand loyalty: the mediating role of brand trust and brand affect. Journal of Product \& Brand Management, 17(3), 154-162. https://doi.org/10.1108/10610420810875070

Kemendikbud. (2019). Permendikbud Nomor 44 Tahun 2019. Permendikbud, 1-25.

Li, C.-K., \& Hung, C.-H. (2009). Whispir Communication Work ow. Journal of Educational Administration, 47, 477-489.

Miles, M. B., \& Huberman, A. M. (1992). Qualitative Data Analysis: A Sourcebook of New Method Terjemahan Tjetjep Rohendi Rohidi. Analisis Data Kualitatif: Buku Sumber tentang Metode-metode Baru. UI-Press.

Rauyruen, P., Miller, K. E., \& Groth, M. (2009). B2B services: Linking service loyalty and brand equity. Journal of Services Marketing, 23(3), 175-186. https://doi.org/10.1108/08876040910955189

Sugiyono. (2011). Statistik Untuk Penelitian. Alfabet. 
Suharjo. (2006). Mengenal pendidikan sekolah dasar teori dan praktek (Depdiknas).

Suprayogi, S. (2008). Pengaruh Perilaku Konsumen terhadap Keputusan Orang Tua dalam Memilih Pendidikan Sekolah Dasar Islam Terpadu. UIN Maulana Malik Ibrahim Malang.

Sutapa, M. (2009). *) Dosen Jurusan Administrasi Pendidikan FIP UNY 1. Administrasi Pendidikan, 1-13.

Verdiyani, R. (2016). Analisis Animo Masyarakat dalam Memilih Sekolah Anak di SD Wuluhadeg dan SD IT Assalaam. Jurnal Pendidikan Guru Sekolah Dasar, 5(23), 262-269.

Zainal, A. (2013). Analisis Pengaruh Kualitas dan Kepercayaan Orang Tua/Wali Murid dalam Memilih Sekolah Menengah Pertama Islam untuk Putra-Putrinya. Jurnal Aplikasi Manajemen, 11(1), 155-160. 